\title{
MEASURING MULTI-DIMENSIONAL POVERTY ANALYSIS IN NEPAL
}

\author{
K.C., Nahakul ${ }^{5}$
}

\section{Abstract}

This study measures the Multi-Dimensional Poverty of the poverty alleviation fund intervention program districts of Nepal. This study uses quantitative only non-experimental, descriptive and exploratory study/survey design applying multi-stage Cluster Random Sampling method. At 5\% margin of error and 95\% confidence level sample size of 2,660 households from 14 districts (two districts from each of seven provinces) is determined as representative for the study. The study finds that Multi-Dimensional Poverty Index (MPI) for the study population is slightly higher (0.133) than that of national level (0. 127) (NPC, 2018). The rational reason is that the current study was based on PAF households only or economically it is homogeneous population. People living in three different places of residence (urban (0.117) and hill (0.116) found to have better quality of life as compared to corresponding other places (Rural (0.153), Mountain (0.162) and Terai (0.138)). Despite having low human development index (NPC, 2014), provinces No.7 recorded the lowest MPI value (0.084), which is urgently needed to be investigated again. By castelethnicity, other categories (e.g., Marwadi, Bangali, Sikh. Jain, Panjawi among others) found lowest poverty level (0.064), followed by Brahmin/Chhetri) (0.069). The highest proportion of headcount ratio (51.5) is noticed in Province No. 2. The gravity of poverty is found high among the Muslim community (44.6). One in every four households (22.9 percent) has the likelihood of being vulnerable to poverty. Households situated in Province No.1 are more vulnerable to poor as compared to population from other provinces.

\section{Keywords:}

Education Index, Health Index, Living Standard Measuremen, Multi-Dimensional Poverty Index,

${ }^{5}$ Mr. K.C. is Ph. D. candidate of Rural Development Department of Tribhuvan University of Nepal. Graduated from summer school (2018) on "Measuring Multi-Dimensional Poverty Analysis from International Development Studies (OPHI) of OXFORD University and Executive Director (August 2015 to November 2019) of Poverty Alleviation Fund Nepal. Email: nahakulkc@gmail.com 


\section{Background}

The Government of Nepal established Poverty Alleviation Fund (PAF) as an autonomous government body in 2003A.D. Objective of the organization is to alleviate extreme poverty in Nepal and build a democratic, just, equitable society; mainstream the excluded communities and to put the poor and disadvantaged groups themselves in the driving seat of development efforts. On the whole, ultimate goal of PAF is to bring about improvement in the livelihoods, living conditions and empowerment of the rural poor with special attention to groups/communities that are traditionally been excluded from the ground of gender, caste/ethnic belongings, residential locations and others. Though the PAF is directed to reduce income poverty and enhance household level food security, it is obvious to expect to have multi-pronged implications to reduce multidimensional poverty of the targeted communities (PAF Act 2063 VS).

The fund has taken a community mobilization approach of organizing members in selfhelp groups called community organizations (COs) to achieve the goal of alleviating poverty. Such COs are self-help groups empowered by PAF to uplift the poorest and most vulnerable communities. Until the date, PAF reached to the targeted ultra-poor and poor 900,000 households and four million of population of its 60 program districts. It facilitated to form 32,360 COs to get support of income generation activities, community infrastructure development and capacity building or both of for households. PAF continued to supporting COs on grant basis; COs were getting fixed grants from PAF on the basis of demand of $\mathrm{CO}$ members and giving to its members on revolving basis charging a nominal interest. For this PAF is utilizing grants received from international donor agencies to help the poor for strengthening of their living in general and to help meet their immediate food security needs in particular ( PAF-MIS, 2018).

Studies have commended the contribution of PAF to alleviate income poverty and improve in household's food security status of the targeted communities. However, there has been no comprehensive study of multidimensional poverty and how that is linked to other development paradigms like the sustainable development goals in recent years. By studying a selected sample of PAF households, this study aims to provide a true and comprehensive picture of both income and multidimensional poverty that exists in Nepal. 
Paradigm shift in studying and analyzing poverty from unit-dimensional - income line (means) approach to multidimensional i.e. human capability (ends) approach is now established. By launching the Multidimensional Poverty Report, National Planning Commission of the Government of Nepal owned the concept, methodology and approach to be used in the study of poverty in Nepal shifting from cost of basic needs (CBN) to MPI approach. Previously, poverty was defined either by counting the number of people living below the poverty line (commonly known as BPL, or poverty threshold), or by evaluating their levels of food sufficiency. Although these methods helped to capture certain aspects of poverty, they are criticized of being insufficient to present various dimensions of deprivations.

PAF as a poverty alleviation intervention was started in a recent post conflict situation in the country in a rush with the objective of availing immediate support for people in the conflict affected rural areas to help them to re-build their survival and livelihood and survival effort. Therefore, it was obvious for PAF to use the classical 'food sufficiency based' target group identification approach and focus on helping the target group in increasing their 'cash income' through direct income generation activities and supporting community level infrastructures. Over the period of last 12 years PAF has many success stories of 'increased income' at household level, however it remains unclear whether PAF's approach have been able to address different non-income aspects of poverty or not. In the meantime, lack of a comprehensive support mechanism that captures multiple dimensions of poverty require the target people to spend much of their time for looking different support from different agencies and this already becomes a time-consuming approach for them. Issues of duplication, repeated/multiple interventions in the same household or non-comprehensive support becoming ineffective in the long run are some of the problems that most of the poverty alleviation interventions in our country are facing, and PAF is also one of them.

Therefore, it becomes essential for PAF to adopt a multidimensional analysis approach of poverty among its target beneficiaries in order to improve its 'target beneficiary identification' process and design the future intervention in such manner that effectively addresses the multiple dimensions of poverty among its target household. Government of Nepal recently issued MPI report of Nepal, in this context this study aims to take it further 
to the context of PAF so that the analysis can be used to broaden PAF's understanding of the poverty of its target groups from a multidimensional perspective resulting into a more comprehensive intervention in future.

The classical approach of defining poverty has not been helpful to get a deeper and wider understanding of the 'poverty' at a given household or a community as a whole, as it did not capture the multiple dimensions and contributing factors of poverty. Hence, we need to look to alternative measures of assessing poverty. Nepal is a least developed country. A quarter of the population lives below the poverty line. However, this measure obviously does not sufficiently capture all aspects of poverty. In that respect, the concept of Multidimensional poverty may be more useful and practical. Multidimensional poverty is a measure of human development and it uses a broad array of indicators to define poverty. The Multidimensional Poverty Index (MPI) may be useful in not only identification of poor people, but also to get a clear picture of the factors that are responsible in creating poverty. Hence, this study sets out with the objective to measure MPI using the established MPI methodology in the study area

\section{Objectives of the Study}

Among others objectives of the undertaking of this MPI study include:

- To measure MPI using the established MPI methodology in the study area,

- To explore the suitability and practicality of using multidimensional poverty analysis approach as an index in assessing poverty in Nepal,

- To identify the causal factors responsible for MPI in the study area,

- To identify the key non-income dimensions of poverty that needs to be comprehensively addressed together with 'income poverty' by poverty alleviation interventions.

The specific objectives are to analyze the, Deprivation in education dimension, Deprivation in Health dimension, Aggregation of MPI, and Policy Implication

\section{Reviews}


The Multidimensional Poverty Index (MPI), of 2010, came out as complementary to monetary measures of poverty by considering overlapping deprivations suffered by individuals at the same time. The index identifies deprivations across the same three dimensions as the Human Development Index (HDI) and shows the number of people who are multidimensional poor and the number of weighted deprivations with which poor households typically contend with. It can be deconstructed by region, ethnicity and other groupings as well as by dimension and indicator, making it a useful tool for policymakers (UNDP, 2016).

Multidimensional poverty index is a measurement of human poverty that considers of multiple deprivations that a person at the individual or at the household level may experience. Based on these deprivations, in any household, a person is classified as poor or non-poor based on a weighted score of his/her deprivations. These data are aggregated into an overall measure of poverty. This measure of poverty can be used at the national and regional levels to make comparisons within countries by various characteristics such as region and ethnic group. Multidimensional poverty is regarded as a valuable complement to income-based poverty measures.

Thus, in the context of the PAF and the country, MPI can be seen as a tool for value addition. The main value that it adds is that by creating a weighted aggregation of different dimensions of poverty, it allows the policymakers to look at poverty using a single measure across multiple dimensions. The strength of the multidimensional approach is that it allows policymakers to improve the ability of the system to address poverty alleviation by specifically focusing on the indicators that the poor are deprived in. This will allow to the localizing MPI as per the recently restructured of the unilateral to the federalism especially at the Local Level Governments.

Bringing NPC's MPI Study in practices

In late 2017, the National Planning Commission released a report entitled "Multidimensional Poverty Index - Analysis towards Action'. This study has used the MPI approach of poverty analysis (for the first time of its publication in any public-sector poverty alleviation program), thus in a way contributes towards the actual use of national 
MPI as an analytical tool. This study will take the MPI study of NPC a bit further as this study will be based on new sets of data of 2018, whereas the NPC MPI is currently based on the data of Multiple Indicator Cluster Survey (MICS) - 2014.

Genesis of MPI

Two concepts and measures of well-being have been accorded to be the most explicit attempts at an international comparison are the physical quality life index (PQLI) by Moris D. Moris in 1976 and the Human Development Index (HDI) by UNDP in 1990. Both concepts are built on the Sen's 'capability and well-being' concepts. In both health and educational achievements are taken as proxies of capability development. The PQLI index is a weighted sum of life expectancy at birth, the infant survival rate and the adult literacy rate. The concept drops the importance of income in measurement of quality of life and or standard of living. The concept and construction of Human Development Index after eleven years of the introduction of PQLI by UNDP, is unwillingly taken as further improvement in Mori's work (Dasgupta, 1993; Srinivasan, 1994; Bardhan \& Klasen, 1999). The first Human Development Report (HDR, 1990) defined human development as denoting 'both the process of widening people's choices and the level of their achieved well-being (Srinivasan, 1994). HDI is the sum of certain normalized indices of per capita national income, life expectancy at birth and the adult literacy rate. Though it was not new, human development concept built on the notion -'the primary objective of development is to benefit people, and income is not the sum total of human life'. The human development index (HDI) was claimed to capture the three essential components of human life: longevity, knowledge and basic income for decent living standard. Longevity and knowledge refer to the formation of human capabilities, and income is a proxy measure for the choices people have in putting their capabilities to use. HDI is the equally weighted sum of deprivation of a country with respect to each of three components: life expectancy at birth, years of schooling and real income per head (Srinivasan, 1994).

MPI in Action

Amartya Sen's works vividly underpinned the concept and measures of human development, has argued powerfully for the need to take a multidimensional approach 
of study and measurement of poverty. His assertion is that 'human lives are battered and diminished in all kinds of different ways, and the first task... is to acknowledge that deprivations of very different kinds have to be accommodated within a general overarching framework' (Sen, 2000). Sen's perspective has implications for poverty and well-being measurement from new and emerging multidimensional frameworks. Taking footsteps on the Sen's pluralistic notion of concepts and measurement of poverty and well-being, the Oxford Poverty \& Human Development Initiative (OPHI) of the Oxford Department of International Development introduced concepts and measures of 'Multidimensional Poverty Index (MPI)' in 2010 a cogent and coherent framework for the measurement of poverty and wellbeing. MPI approach is claimed to forward a comprehensive definition and measure of acute multidimensional poverty and to reflect deprivations in very rudimentary services and core human functioning (Alkire \& Santos, 2010). MPI reveals a different pattern of poverty than income poverty, as it illuminates a different set of deprivations. The MPI has three dimensions: health, education, and standard of living and measures levels of deprivations or well-beings using ten indicators. Each dimension is equally weighted; each indicator within a dimension is also equally weighted. The MPI reveals the combination of deprivations that batter a household at the same time. A household is identified as multidimensionally poor if, and only if, it is deprived in some combination of indicators whose weighted sum is 30 percent or more of the dimensions.

The major bodies of concepts and measures of poverty/well-being from multidimensional perspectives are better explained, interpreted and or rooted to the Sen's (1980, 1984, 1985a, 1985b, 1987, 1990b, 1992, 1993, 1995, 1999a as in (Robeyns, 2005) concept of 'capabilities, well-being and functioning'. The capability approach is widely taken as a broad normative framework for the evaluation and assessment of individual well-being and social arrangements. It can be used to evaluate several aspects of people's wellbeing, such as inequality, poverty, the well-being of an individual or the average wellbeing of the members of a group (Robeyns, 2005). The perspective takes expansion of individual's choices through 'capability expansion' as both means and ends of human 'well-being'. It takes satisfaction of individual's basic needs as 'ends' and the endowments and entitlements a person has as 'means of poverty analysis. Both means and 'ends' for the personal 'well-beings' are determined by the capability she/he exercises in life. 
The 2030 development agenda-17 sets of Sustainable Development Goals (SDGs) acknowledges the eradication of poverty of all forms and dimensions. The first and foremost is eradiation of extreme poverty - the greatest global challenge and an indispensable requirement for achieving sustainable development goals. Good health and wellbeing, quality education, gender equality and clean water and sanitation are considered integral to attainment of individual and social wellbeing and to alleviate multidimensional poverty.

Sabina Alkire (2018), the proponent of MPI concepts and methods sees with the advent of the Sustainable Development Goals (SDGs), multidimensional poverty appears to be graduating from the margins to the mainstream poverty research. First of all, SDGs framed development multidimensionally, since the 17 goals and 169 targets are integrated and indivisible and balance the three dimensions of sustainable development: the economic, social and environmental.

Clear from the discussion is that concept of poverty is essentially multidimensional and income is only one of many factors in the identification of the poor. If we opt to argue poverty as the failure of basic capabilities to reach minimally acceptable levels and capacity is a function of income, health, housing, the provision of public goods, then it is essential to measure povertv from a multidimensional perspective. The multidimensional

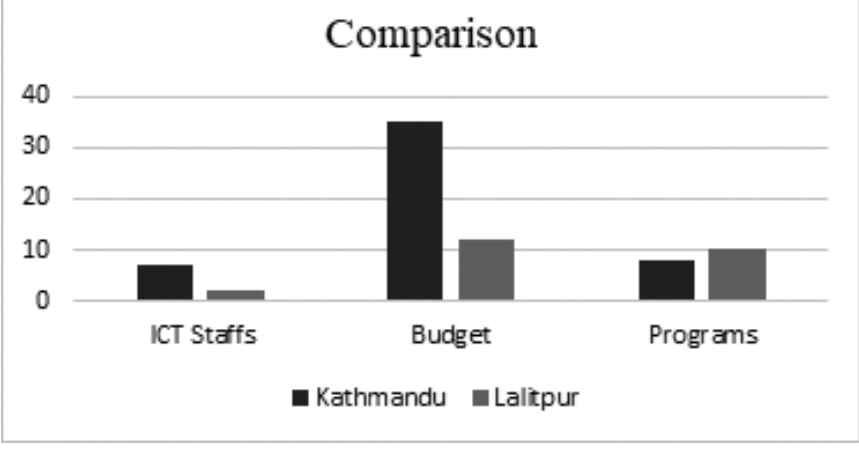

measurement of poverty remains an area to be explored from country and community specific perspective.

\section{Methodology}

This study adopts a quantitative only non-experimental, descriptive and exploratory study/ survey design applying multi-stage Cluster Random Sampling method. At 5\% margin 
of error and 95\% confidence level sample size of 2,660 households from 14 districts (two districts from each of seven provinces) is determined as representative for the study. Following the practice of other household surveys like NLSS and NDHS, 20 households

\section{ICT Staffs}

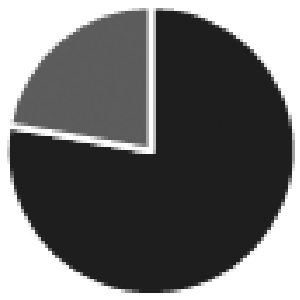

- Kathmandu = Lalitpur

is allocated per cluster. This produces a total of $133(2260 / 20=133)$ clusters from the 14 survey districts.

Sampling Design

The current study is based on quantitative data collection. Study of PAF households, sampling design and sample size is determined by the study team in consultation with PAF Oversight Study Team (PAFOST).

Major data in the study is collected from primary sources i.e. survey of 2,660 households. Secondary sources are reviewed from published and unpublished materials to establish the study on MPI indicators. This type of research employed the quantitative research methods for data generation.

Sample Size Determination

The primary statistical consideration determining sample size is the precision with which the MPI is to be estimated. As the estimate of the population parameters is not known we have to consider the largest possible value for $p(1-p)$. Thus, whenever there is any question regarding an appropriate planning value for $p$, we suggest using $p=0.50$ since the value provides the largest sample size recommendation. If the proportion is different 
than the 0.50 planning value, the precision statement will be better than anticipated. For the value of $p$, the current study adopted indicator of MPI is 0.127 (NPC, 2018) which was estimated for Nepal. This means that multidimensionally poor people in Nepal experience $12.7 \%$ of the total deprivations that would be experienced if all people were deprived in all indicators.

The desire margin of error $(\mathrm{E})$ for estimation of the population proportion is almost always 0.10 or less. In the study, a planning value of $p=0.127$, household size of PAF working district, $\mathrm{N}=460,691$ and $\mathrm{d}=0.05$ have been provided following Kerjcie and Morgan method (1970) to estimate the required sample size.

$$
\mathrm{n}==170.3
$$

where $\mathrm{n}=$ Required Sample Size

Sampling statisticians usually want to design surveys that have a clustering effect in the range of $1.5-3.0$, and certainly no greater than 4.0. Finding from prior behavioral surveys in Nepal also suggest 2.0 (design effect) should be minimum. If we multiply by design effect, 2, the sample size would be 340. 6. If we add 10 percent as non-response and refusal rate to that, then the required sample size for seven provinces is $2622((340.5+$ 34.1) $x 7$ ) households.

The primary focus of sample design is to ensure the survey of adequate households enabling to determine precise value of MPI by the survey district, province and ecological belt, as well as by social inclusion categories and household wealth level. Accordingly, 14 of the 60 PAF intervention districts (2 from each of seven provinces) are selected as sample districts. Except districts of province two and six, the 60 districts have been stratified into two as i) Hill and Mountain districts and ii) Terai districts. Both of the selected districts of province two are Terai, and of province six are hill and Mountain. From the five provinces one each district of hill/mountain region and one of Terai region are selected.

Measurement of Poverty

Following the structure of the Adjusted Headcount $\left(\mathrm{M}_{0}\right)$ measure of AF methodology, the MPI combines two key pieces of information: (1) the proportion or incidence of people 
(within a given population) whose share of weighted deprivations is $\mathrm{k}$ or more and (2) the intensity of their deprivation: the average proportion of (weighted) deprivations they experience. Formally, the first component is called the multidimensional headcount ratio (H):

$$
H=\frac{q}{n}
$$

Here $\mathrm{q}$ is the number of people who are multidimensionally poor and $\mathrm{n}$ is the total population. The second component is called the intensity (or breadth) of poverty (A). It is the average deprivation score of multidimensionally poor people and can be expressed as:

$$
A=\frac{\sum_{i=1}^{n} c_{i}(k)}{q}
$$

where $c_{i}(k)$ is the censored deprivation score of individual $i$ and $q$ is the number of people who are multidimensionally poor.

(Table No 1: Multidimensional Poverty Index)

\begin{tabular}{|l|l|l|l|}
\hline Dimension & Indicator & Deprived indicators & $\begin{array}{l}\text { Relative } \\
\text { weight }\end{array}$ \\
\hline Education & $\begin{array}{l}\text { Year of } \\
\text { schooling }\end{array}$ & $\begin{array}{l}\text { No household member has completed five } \\
\text { years of schooling. }\end{array}$ & $1 / 6$ \\
\cline { 2 - 4 } & $\begin{array}{l}\text { Child School } \\
\text { attendance }\end{array}$ & $\begin{array}{l}\text { Any school-aged child is not attending school } \\
\text { up to class } 8\end{array}$ & $1 / 6$ \\
\hline Health & $\begin{array}{l}\text { Child Mor- } \\
\text { tality }\end{array}$ & Any child has died in the family. & $1 / 6$ \\
\cline { 2 - 5 } & Nutrition & $\begin{array}{l}* \text { Any adult or child for whom there is nutri- } \\
\text { tional information is malnourished. }\end{array}$ & $1 / 6$ \\
\hline
\end{tabular}




\begin{tabular}{|c|c|c|c|}
\hline \multirow{6}{*}{$\begin{array}{l}\text { Living } \\
\text { Standard }\end{array}$} & Electricity & The household has no electricity. & $1 / 18$ \\
\hline & $\begin{array}{l}\text { Improved } \\
\text { sanitation** }\end{array}$ & $\begin{array}{l}\text { The household's sanitation facility is not } \\
\text { improved, or it is improved but shared with } \\
\text { other households. }\end{array}$ & $1 / 18$ \\
\hline & $\begin{array}{l}\text { Safe drink- } \\
\text { ing water** }\end{array}$ & $\begin{array}{l}\text { The household does not have access to safe } \\
\text { drinking water (according to MDG guide- } \\
\text { lines) or safe drinking water is more than a } \\
\text { 30-minute walk from home roundtrip }\end{array}$ & $1 / 18$ \\
\hline & $\begin{array}{l}\text { Flooring and } \\
\text { roofing }\end{array}$ & The household has a dirt, sand or dung floor. & $1 / 18$ \\
\hline & Cooking fuel & $\begin{array}{l}\text { The household cooks with dung, wood or } \\
\text { charcoal. }\end{array}$ & $1 / 18$ \\
\hline & $\begin{array}{l}\text { Asset owner- } \\
\text { ship }\end{array}$ & $\begin{array}{l}\text { The household does not own more than one } \\
\text { radio, TV, telephone, bike, motorbike or re- } \\
\text { frigerator and does not own a car or truck. }\end{array}$ & $1 / 18$ \\
\hline
\end{tabular}

(Study, 2018)

The MPI is the product of both: MPI $=\mathrm{H} \times \mathrm{A}$.

Vulnerability to Poverty and Severe Poverty: The first refers to people who are 'vulnerable' to poverty. This is defined as the people whose deprivation score is between 20 and 33 percent $\left(20 \%<\mathrm{c}_{\mathrm{i}}<33 \%\right)$. The second refers to people in severe poverty. This is defined as people whose deprivation score is 50 percent or more $\left(c_{i}>50 \%\right)$ as shown in the following table.

(Table No 2: Level of Poverty)

\begin{tabular}{|l|l|}
\hline Level of Poverty & Range of MPI \\
\hline Non-poor & $<0.33333$ \\
\hline Vulnerable to poverty & $0.20000-0.33332$ \\
\hline MPI Poor & $=>0.33333$ \\
\hline Severe poverty & $>0.50000$ \\
\hline
\end{tabular}

(Study, 2018)

The dimensions, indicators, deprivation thresholds and weights of the MPI 
*Adults are considered malnourished if their BMI is below $18.5 \mathrm{~m} / \mathrm{kg}^{2}$. Children are considered malnourished if their z-score of weight-for-age is below minus two standard deviations from the median of the reference population.

${ }^{* *} \mathrm{~A}$ household is considered to have access to improved sanitation if it has some type of flush toilet or latrine, or ventilated improved pit or composting toilet, provided that they are not shared.

${ }^{* * *}$ A household has access to clean drinking water if the water source is any of the following types: piped water, public tap, borehole or pump, protected well, protected spring or rainwater, and it is within a distance of 30 minutes' walk (roundtrip).

\section{Discussion and Results}

Interview completion status of the theoretical sample of 2,660 households by times visited for interview is presented in Table 3. Apparent to see from the table is that on the whole the survey achieved 99.8 percent response rate, of which 94.3 percent is achieved at the first visit of interview and 5.5 percent at second and more visits.

(Table No. 3: Result of survey by time attempted for interview by residential attributes)

\begin{tabular}{|c|c|c|c|c|c|c|c|c|}
\hline \multirow{3}{*}{$\begin{array}{l}\text { Residential At- } \\
\text { tributes }\end{array}$} & \multicolumn{7}{|c|}{ Interview Completion Status by Times visited for survey } & \multirow{3}{*}{$\begin{array}{c}\text { Total HHs } \\
\text { Visited }\end{array}$} \\
\hline & First visit & $2^{\text {nd }}$ & nore & & & & & \\
\hline & $\%$ & $\mathrm{~N}$ & $\%$ & $\mathrm{~N}$ & $\%$ & $\mathrm{~N}$ & $\%$ & \\
\hline
\end{tabular}

Ecological

Region

$\begin{array}{lrrrrrrrrr}\text { Mountain } & 299 & 99.7 & 1 & 0.3 & 300 & 100.0 & 0 & 0.0 & 300 \\ \text { Hills } & 887 & 92.4 & 70 & 7.3 & 957 & 99.7 & 3 & 0.3 & 960 \\ \text { Tarai } & 1322 & 94.4 & 75 & 5.4 & 1397 & 99.8 & 3 & 0.2 & 1,400 \\ \text { Province } & & & & & & & & & \\ \text { Province 1 } & 338 & 88.9 & 42 & 11.1 & 380 & 100.0 & 0 & 0.0 & 380 \\ \text { Province 2 } & 403 & 96.0 & 16 & 3.8 & 419 & 99.8 & 1 & 0.2 & 420 \\ \text { Province 3 } & 379 & 99.7 & 1 & 0.3 & 380 & 100.0 & 0 & 0.0 & 380 \\ \text { Province 4 } & 325 & 90.3 & 33 & 9.2 & 358 & 99.4 & 2 & 0.6 & 360\end{array}$


$\begin{array}{llllllllll}\text { Province } 5 & 371 & 97.6 & 8 & 2.1 & 379 & 99.7 & 1 & 0.3 & 380\end{array}$

$\begin{array}{llllllllll}\text { Province } 6 & 327 & 90.8 & 32 & 8.9 & 359 & 99.7 & 1 & 0.3 & 360\end{array}$

$\begin{array}{llllllllll}\text { Province } 7 & 365 & 96.1 & 14 & 3.7 & 379 & 99.7 & 1 & 0.3 & 380\end{array}$

Districts of Survey

$\begin{array}{llllllllll}\text { Sunsari } & 209 & 87.1 & 31 & 12.9 & 240 & 100.0 & 0 & 0.0 & 240\end{array}$

$\begin{array}{llllllllll}\text { Khotang } & 129 & 92.1 & 11 & 7.9 & 140 & 100.0 & 0 & 0.0 & 140\end{array}$

$\begin{array}{llllllllll}\text { Dhanusha } & 190 & 95.0 & 9 & 4.5 & 199 & 99.5 & 1 & 0.5 & 200\end{array}$

$\begin{array}{llllllllll}\text { Rautahat } & 213 & 96.8 & 7 & 3.2 & 220 & 100.0 & 0 & 0.0 & 220\end{array}$

Sindhupal-

$\begin{array}{llllllllll}\text { chwk } & 179 & 99.4 & 1 & 0.6 & 180 & 100.0 & 0 & 0.0 & 180\end{array}$

$\begin{array}{llllllllll}\text { Chitwan } & 200 & 100.0 & 0 & 0.0 & 200 & 100.0 & 0 & 0.0 & 200\end{array}$

$\begin{array}{llllllllll}\text { Gorkha } & 233 & 89.6 & 26 & 10.0 & 259 & 99.6 & 1 & 0.4 & 260\end{array}$

$\begin{array}{lrllllllll}\text { Nawalpur } & 92 & 92.0 & 7 & 7.0 & 99 & 99.0 & 1 & 1.0 & 100\end{array}$

$\begin{array}{llllllllll}\text { Pyuthan } & 138 & 98.6 & 1 & 0.7 & 139 & 99.3 & 1 & 0.7 & 140\end{array}$

$\begin{array}{llllllllll}\text { Dang } & 233 & 97.1 & 7 & 2.9 & 240 & 100.0 & 0 & 0.0 & 240\end{array}$

$\begin{array}{llllllllll}\text { Rukum-West } & 207 & 86.3 & 32 & 13.3 & 239 & 99.6 & 1 & 0.4 & 240\end{array}$

$\begin{array}{llllllllll}\text { Mugu } & 120 & 100.0 & 0 & 0.0 & 120 & 100.0 & 0 & 0.0 & 120\end{array}$

$\begin{array}{lrrrrrrrrr}\text { Achham } & 180 & 100.0 & 0 & 0.0 & 180 & 100.0 & 0 & 0.0 & 180\end{array}$

\begin{tabular}{lrrrrrrrrr} 
Kanchanpur & 185 & 92.5 & 14 & 7.0 & 199 & 99.5 & 1 & 0.5 & 200 \\
\hline Total & 2,508 & 94.3 & 146 & 5.5 & 2,654 & 99.8 & 6 & 0.2 & 2,660 \\
\hline
\end{tabular}

(Study, 2018)

Of the six households denied to participate in the survey are three each from hills and Tarai regions, two from province four and one each from provinces two, five, six and seven and one each from districts Dhanusha, Gorkha, Nawalpur, Pyuthan, Rukum-west and Kanchanpur.

Figure 2 shows that the largest uncensored headcount ratio is found in the cooking fuel indicator (74.51 percent) for Nepal as a whole whereas 100 percent of assets is noticed, however, this proportion of population deprived has gone down by about 72 percent $(28.4$ percent) while data are censored $(=>33)$. 
Figure 1: Proportion of Deprived Population

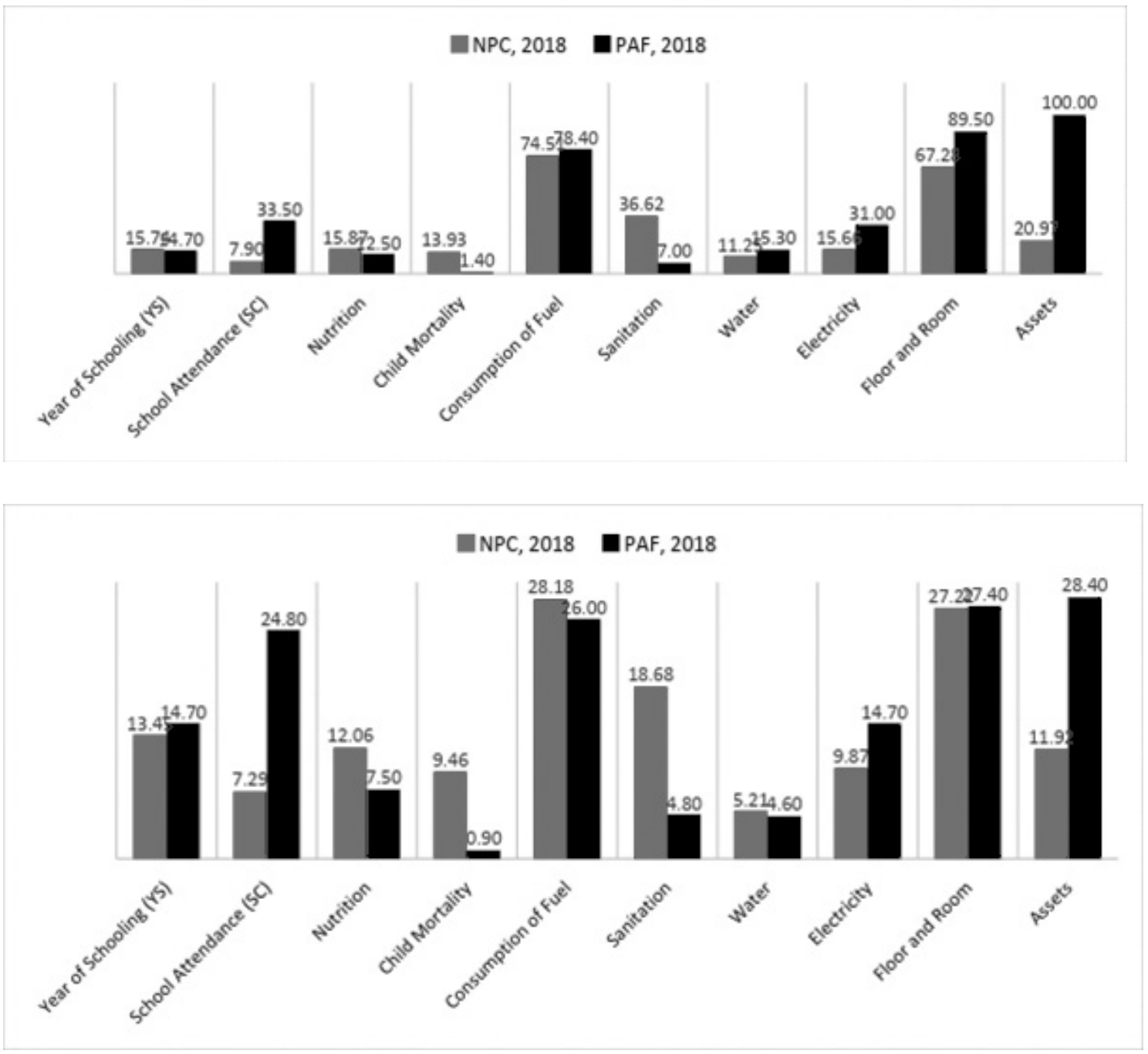

(Study, 2018)

(Table No 4: Multidimensional Poverty Index (MPI), when k=>0.33)

\begin{tabular}{|c|c|c|c|c|c|c|c|c|}
\hline \multirow{2}{*}{$\begin{array}{l}\text { Selected Some } \\
\text { Background } \\
\text { Characteristics }\end{array}$} & \multicolumn{3}{|c|}{$\%$ share within } & \multicolumn{2}{|c|}{$\begin{array}{l}\text { Proportion of popu- } \\
\text { lation }\end{array}$} & \multicolumn{2}{|c|}{$\begin{array}{l}\% \text { share be- } \\
\text { tween }\end{array}$} & $\mathrm{N}$ \\
\hline & $\begin{array}{r}\text { MPI } \\
(\mathrm{H} \mathrm{x} \\
\mathrm{A})\end{array}$ & $\begin{array}{r}\text { Inci- } \\
\text { dence } \\
\mathrm{H}\end{array}$ & $\begin{array}{r}\text { Inten- } \\
\text { sity } \\
\mathrm{A}\end{array}$ & $\begin{array}{l}\text { Vulnerable } \\
\text { to Poverty }\end{array}$ & $\begin{array}{l}\text { Severe } \\
\text { Poverty }\end{array}$ & $\%$ & MPI & \\
\hline
\end{tabular}


K.C., Nahakul

\begin{tabular}{|c|c|c|c|c|c|c|c|c|}
\hline \multicolumn{2}{|c|}{ Place of Residence } & \multirow[b]{2}{*}{25.3} & \multirow[b]{2}{*}{45.7} & \multirow[b]{2}{*}{25.0} & \multirow[b]{2}{*}{9.9} & \multirow[b]{2}{*}{43.3} & \multirow[b]{2}{*}{0.051} & \multirow[b]{2}{*}{1399} \\
\hline Urban & 0.117 & & & & & & & \\
\hline Rural & 0.153 & 31.8 & 48.0 & 20.5 & 11.6 & 52.7 & 0.080 & 1255 \\
\hline \multicolumn{9}{|c|}{ Ecological Region } \\
\hline Mountains & 0.162 & 34.0 & 47.6 & 23.3 & 14.3 & 11.3 & 0.018 & 300 \\
\hline Hills & 0.116 & 25.8 & 45.1 & 22.7 & 8.9 & 36.1 & 0.042 & 957 \\
\hline Terai & 0.138 & 28.9 & 47.6 & 22.9 & 11.2 & 52.6 & 0.073 & 1397 \\
\hline \multicolumn{9}{|l|}{ Provinces } \\
\hline Province 1 & 0.206 & 43.9 & 46.9 & 29.5 & 17.4 & 14.3 & 0.029 & 380 \\
\hline Province 2 & 0.213 & 41.3 & 51.5 & 21.5 & 20.8 & 15.8 & 0.034 & 419 \\
\hline Province 3 & 0.090 & 19.7 & 45.7 & 20.5 & 4.7 & 14.3 & 0.013 & 380 \\
\hline Province 4 & 0.104 & 23.7 & 43.8 & 22.1 & 5.6 & 13.5 & 0.014 & 358 \\
\hline Province 5 & 0.110 & 24.8 & 44.5 & 20.1 & 8.2 & 14.3 & 0.016 & 379 \\
\hline Province 6 & 0.109 & 24.0 & 45.5 & 20.6 & 10.3 & 13.5 & 0.020 & 359 \\
\hline Province 7 & 0.084 & 19.3 & 44.2 & 25.9 & 6.6 & 14.3 & 0.012 & 379 \\
\hline \multicolumn{9}{|c|}{ Caste/Ethnic Group } \\
\hline $\begin{array}{r}\text { Brahmin/Chhe- } \\
\text { tri } \\
\end{array}$ & 0.069 & 15.8 & 43.7 & 23.7 & 4.8 & 21.3 & 0.015 & 565 \\
\hline $\begin{array}{r}\text { Disadvantaged } \\
\text { Non-Dalit } \\
\text { Terai Caste }\end{array}$ & 0.154 & 31.7 & 48.7 & 23.3 & 14.9 & 7.6 & 0.012 & 202 \\
\hline Dalit & 0.189 & 39.2 & 48.3 & 21.2 & 17.5 & 29.9 & 0.057 & 794 \\
\hline $\begin{array}{r}\text { Relatively } \\
\text { Disadvantaged } \\
\text { Janjati }\end{array}$ & 0.119 & 26.4 & 44.9 & 25.4 & 7.4 & 31.5 & 0.037 & 836 \\
\hline $\begin{array}{r}\text { Relatively } \\
\text { Advantaged } \\
\text { Janjati } \\
\end{array}$ & 0.090 & 20.6 & 43.6 & 13.5 & 5.6 & 4.7 & 0.004 & 126 \\
\hline Muslim & 0.228 & 44.6 & 51.2 & 18.9 & 23.0 & 2.8 & 0.006 & 74 \\
\hline Others & 0.100 & 20.8 & 47.9 & 26.3 & 3.5 & 2.1 & 0.001 & 57 \\
\hline Total & 0.133 & 28.4 & 46.8 & 22.9 & 10.7 & 100.0 & 1.000 & 2654 \\
\hline Nepal & 0.127 & 28.6 & 44.2 & & & & & \\
\hline
\end{tabular}

(Study, 2018) 


\section{Conclusion}

Table 4 represents the multidimensional poverty index. The MPI for the study population is slightly higher $(0.133)$ than that of national level $(0.127$ : NPC, 2018). The plausible reason is that the current study was based on PAF households only or economically it is homogeneous population. People living in three different places of residence (urban (0.117) and hill (0.116) found to have better quality of life as compared to corresponding other places (Rural (0.153), Mountain (0.162) and Terai (0.138)). Despite having low human development index (NPC, 2014), provinces No.7 recorded the lowest MPI value (0.084), which is urgently needed to be investigated again. By caste/ethnicity, other categories (e.g., Marwadi, Bangali, Sikh. Jain, Panjawi among others) found lowest poverty level (0.064), followed by Brahmin/Chhetri) (0.069). The highest proportion of headcount ratio (51.5) is noticed in Province No. 2. The gravity of poverty is found high among the Muslim community (44.6). One in every four households (22.9 percent) has the likelihood of being vulnerable to poverty. Households situated in Province No.1 are more vulnerable to poor as compared to population from other provinces.

Poverty is generally measured based on three indicators, each of which measures a specific aspect of poverty. These are (i) the head count index, which measures the incidence (or prevalence) of poverty; (ii) poverty gap index, which measures the intensity, and (iii) the squared poverty gap index, which measures the severity.

The study had major findings in the following sectors;

Deprivation in education dimension

- Nearly 27 percent of the study households found to be deprived of education and knowledge dimensions of MPI. Current non-schooling of any of school aged children (aged five and seventeen) is counted from 18 percent of the study households and none of the family members 15 and above completed five years of education/schooling in 11 percent of the study households.

Deprivation in Health dimension

- As program construct a composite of all types of health deprivation such as stunting, wasting, and underweight of children 6 to 59 months of age (under five); incidences of 
infant and child mortality during last five years and proportion women falling below 18.5 BMI, 26 percent households accounted deprived in health dimension of MPI against only six percent taking only OPHI/NPC (2018) methodology.

- The study found prevalence of stunting among (short in height for age) children in 11 percent households; prevalence of wasting (weight for height) in five percent households; prevalence of underweight (weight for age) nearly in nine-percent households. Women in reproductive age lagging behind in standard BMI $(>18.5)$ is observed nearly in 13 percent of the study households and that of incidence of infant or child mortality during last five years in bit more than 1 percent households.

\section{Aggregation of MPI}

- The study estimated aggregated MPI value of 0.133 . It is highest in provinces two $(0.213)$ and one $(0,206)$ and lowest in Provinces seven $(0.084)$ and three $(0.090)$. The head count index $(\boldsymbol{H})$ of poverty (population in MPI deprivation) is estimated at 28.4 percent and the intensity of poverty $(A)$ is 47 .

- Muslim is the most multidimensional deprived caste/ethnic community (45\%) followed by Dalits (39\%) and disadvantaged Janajatis (32\%).

- 23 percent of the study population is vulnerable to poverty/deprivation (with MPI value in between 0.20 to 0.332 ) and 11 percent is in the state of severe deprivation (MPI $>0.50)$. Extent of severe poverty again high in Muslim communities (23\%) and for Dalits $(17.5 \%)$.

Policy Implications

- Education still remains the major explanatory of multidimensional deprivation of households and population

- Dimensions of living standard deprivation such as housing condition, assets ownership, sanitation and toilet facilities, and cooking fuel can be seen as explaining factors of household income level, whereas provision of safe drinking water and electricity may be explained by local community infrastructure development.

- There are emerging opportunities to the Local Level Government for the localizing 
multi dimension poverty and develop policy to support the poverty deprivation cutoff households.

Therefore, there are still many implications to measure the poverty by using Multidimensional Poverty Index.

\section{References}

Alkire, S. (2005). Subjective Quantitative studies of Human Agency. Social Indicators Research, 74(1), pp. 217-260. URL: http://www.jstor.org/stable/27522243. Accessed: 13/09/2012.

Alkire, S. (2010). Human Development: Definitions, Critiques, and Related Concepts (Background paper for the 2010 Human Development Report), OPHI WORKING PAPER NO. 36

Alkire, S. (2018). The Research Agenda on Multidimensional Poverty Measurement: Important and As-yet Unanswered Questions. Oxford Poverty \& Human Development Initiative (OPHI), OPHI WORKING PAPER NO. 119.

Alkire, S. and J.M. Roche. (2011). Beyond headcount: Measures that reflect the breadth and Components of Child Poverty. Oxford Poverty \& Human Development Initiative (OPHI); OPHI Working Paper No. 45.

Alkire, S. and J.M., Roche. (2011). Beyond Headcount: Measures that Reflect the Breadth and Components of Child Poverty. Oxford Poverty and Human Development Initiative (OPHI) Working Paper No. 45.

Alkire, S. and M.E., Santos (2010). Acute Multidimensional Poverty: A New Index for Developing Countries. Oxford Poverty and Human Development Initiative (OPHI): Working Paper NO. 38

Alkire, S., A. Conconi \& J. M. Roche. (2013). Multidimensional Poverty Index 2013: Brief Methodological Note and Results. Oxford Poverty \& Human Development Initiative (OPHI).

Alkire, S., and Foster, J. (2008). Counting and Multidimensional Poverty Measurement, 
Oxford Poverty and Human Development Initiative, Working Paper No. 7, Oxford Department of International Development, University of Oxford. Bardhan, K. and S. Klasen. (1999). UNDP's Gender-Related Indices: A Critical Review. World Development, 27(6), pp. 985-1010. www.elsevier.com/locate/wordldev.

Baulch, B. (2006 first published 1996). The New Poverty Agenda: A Disputed Consensus (Editorial). IDS Bulletin, 37(4), pp. 82-90.

CBS. (2005). Poverty Trends in Nepal (1995-96 and 2003-04). Kathmandu: Central Bureau of Statistics.

CBS. (2009). Report on the Nepal Labour Force Survey 2008. Kathmandu: Central Bureau of Statistics.

CBS. (2011a). Poverty in Nepal 2010/11. Kathmandu: Central Bureau of Statistics.

CBS. (2012). National Population and Housing Census 2011, Volume-1 (National Report). Kathmandu: Central Bureau of Statistics.

Chambers, R. (1995). Poverty and livelihoods: Whose reality counts? The Hague: Institution of Development Studies (Discussion Paper No. 347).

Colclough, C. (1997). Education, health, and the market: an introduction. In Marketezing Education and Health in Developing Countries, Miracle or Mirage. Oxford: Clarendon Press, pp. 3-27.

Dasgupta, P. (1993). An Inquiry into Wellbeing and Destitution, Oxford: Clarendon Press.

Delamonica, E. and A. Minujin. (2007). Incidence, depth and severity of children in poverty. Social Indicators Research, 82(2), pp. 361-374. http://www.jstor.org/ stable/. Accessed: 16/12/2013.

Glewwe, P. \& J. Van Der Gaag. (1990). Identifying the Poor in Developing Countries: Do Different Definitions Matter? World Development, 18(6), pp.803-814.

Gordon, D. S. Nandy, C. Pantazis, S. Pemberton and P. Townsend. (2003). Child poverty in the developing world. Bristol UK: The Policy Press. aa.ecn.cz/img_ 
upload/.../Child_poverty.pdf.

Gwatkin, D.R., S. Rutstein, K. Johnson, R.P. Pande, and A. Wagstaff. (2000). Socioeconomic differences in health, nutrition and poverty. HNP/Poverty Thematic Group of The World Bank. Washington, D.C.: The World Bank.

Hagenars, A. \& K. de Vos. (1988). The Definition and Measurement of Poverty. The Journal of Human Resources, 23(2), pp. 211-221. http://links.jstor.org/ sici?sici=0022-. Accessed: Jan 28, 2008.

Notten, G. \& C. de Neubourg. (2011). Monitoring Absolute and Relative Poverty: "Not Enough" is not the Same as "Much Less". The Review of Income and Wealth, 57(2), pp. 247-269. DOI: 10.1111/j.1475-4991.2011.00443.x. Accessed: August $29,2013$.

NPC and OPHI. (2018). Nepal's multidimensional poverty index: Analysis towards action. Kathmandu: National Planning Commission (NPC) and Oxford Poverty and Human Development Initiative (OPHI) University of Oxford.

Oxford Poverty and Human Development Initiative (2017). "Nepal Country Briefing”, Multidimensional Poverty Index Data Bank. OPHI, University of Oxford.

Ravallion, M. \& B. Bidani. (1994). How Robust Is a Poverty Profile? The World Bank Economic Review, 8(1), pp. 75-102. URL: http://www.jstor.org/stable/3989887. Accessed: 21/08/2013.

Robeyns, I. (2005). The Capability Approach: a theoretical survey. Journal of Human Development, 6(1), pp. 93-117. http://dx.doi.org/10.1080/146498805200034266. Accessed: 13 August 2012.

Sen, A. (2000). A Decade of Human Development. Journal of Human Development, 1(1), pp. 17-23 http://dx.doi.org/10.1080/14649880050008746. Assessed by HINARI on: 18 August 2012.

UNDP (2016). Human development report 2016: Human development for everyone. United Nations Development Programme (UNDP). http:/hdr.undp.org/sites/ default/files/2016_human_development_report.pdf. Accessed: 01/07/2018. 
WHO. (2011). WHO Anthro for Personal Computers Manual. Geneva: World Health Organization.

WHO. (2015). Health in 2015: from MDGs, Millennium Development Goals to SDGs, Sustainable Development Goals. Geneva: World Health Organisation (WHO). 